\title{
PERANAN PERSONIL SEKOLAH DALAM PELAKSANAAN BIMBINGAN DAN KONSELING DI SMKN 1 MANADO
}

\author{
Sukatma \\ Program Studi Bimbingan dan Konseling Fakultas Ilmu Pendidikan Universitas Negeri Manado \\ Korespondensi: Jln. Kampus Universitas Negeri Manado, Tondano, Minahasa, \\ Sulawesi Utara, 95618
}

\begin{abstract}
This research was aimed at: 1) explaining positive description of the roles of school principal, counselors, vice principal, administrative personnel in SMK Negeri Manado, 2) explaining positive description on guidance and counseling program in SMK Negeri Manado, and 3) explaining the relationship among school principal, counselors, vice principal, administrative personnel in carrying out guidance and counseling program SMK Negeri Manado. The method employed in this study was survey which described factors related the roles of school principal, counselors, vice principal, administrative personnel in carrying out guidance and counseling program SMK Negeri Manado. The findings showed that there was 1) positive description about the roles school principal, counselors, vice principal, administrative personnel in SMK Negeri Manado, 2) positive description about guidance and counseling program in SMK Negeri Manado, 3) positive description about the roles school principal, counselors, vice principal, administrative personnel in carrying out guidance and counseling program in SMK Negeri Manado. These imply that positive that the roles school principal, counselors, vice principal, administrative personnel has positive influence toward guidance and counseling program in SMK Negeri Manado. Consequently, the higher the roles assumed by the school principlal, the better guidance and counseling program will be and vise versa. Based on the findings, it was suggested that 1) the school counselor keep giving information to students about guidance and counseling services that they may use. 2) School should provide facility to support guidance and counseling program, $3)$ students use all services provided in guidance and counseling program.
\end{abstract}

Kata kunci: personil sekolah (kepala sekolah, guru BK, wali kelas, tata usaha), bimbingan dan konseling

\section{PENDAHULUAN}

$\mathrm{P}$ endidikan merupakan suatu komponen yang sangat menentukan bahkan hal yang sangat mendasar dalam mendapatkan dan menciptakan sumber daya manusia yang berkualitas. Karena dengan memperoleh pendidikan yang optimal mendapatkan manusiamanusia potensial yang dapat mem- bangun dirinya dan dapat membangun bangsa ke arah yang lebih baik.

Undang-undang No. 2 tahun 1989 tentang Sistem Pendidikan Nasional menyebutkan bahwa "Pendidikan adalah usaha sadar untuk menyiapkan peserta didik melalui kegiatan bimbingan, pengajaran dan latihan bagi peranannya dimasa datang". Upaya pendidikan ber- 
dasarkan pengertian tersebut mencakup kawasan yang amat luas yang semua mengacu pada pengembangan individu. Dalam cakupannya yang amat luas itu, upaya pendidikan secara menyeluruh meliputi tiga kegiatan yaitu kegiatan bimbingan, kegiatan pengajaran dan kegiatan latihan. Ketiga kegiatan ini saling mengait, saling menunjang seringkali yang satu tidak dapat dipisahkan dan yang lainnya.

Untuk mencapai manusia Indonesia yang unggul adalah suatu cita-cita luhur yang harus diupayakan oleh instansi resmi yakni sekolah sebagai sumber "out put". Untuk itu saat ini sementara diberlakukan apa yang dinamakan "Manajemen Peningkatan Mutu Berbasis Sekolah" dengan tujuan mendirikan atau memberdayakan sekolah melalui pemberian kewenangan (otonomi) kepada sekolah dan mendorong sekolah melakukan pengambilan keputusan secara partisipatif. Lebih rinci, Manajemen Peningkatan Mutu Berbasis Sekolah yang disingkat MPBS bertujuan : meningkatkan mutu pendidikan melalui kemandirian dan inisiatif sekolah dalam mengelolah dan memberdayakan sumber daya yang tersendiri, meningkatkan kepedulian warga sekolah dan masyarakat dalam pengelenggaraan pendidikan melalui pengambilan keputusan bersama, meningkatkan tanggung jawab sekolah kepada orang bersama, meningkatkan tanggung jawab sekolah kepada orang tua, masyarakat, dan pemerintah tentang mutu sekolahnya, dari meningkatkan kompetisi yang sehat antara sekolah tentang mutu pendidikan yang akan dicapai (Depdiknas, 2001:4).

Bukanlah hal yang mudah menciptakan manusia Indonesia unggul, karena setiap sekolah baik yang dikelolah oleh pemerintah., yayasan maupun masyarakat memiliki karakteristik yang berbeda dilihat dari input berupa: kebijakan, tujuan dan sasaran mutu, sumber daya yang tersedia, staf yang kompeten dan berdedikasi, memiliki harapan dan prestasi yang tinggi; fokus pada pelanggan (siswa) manajemen (Depdiknas 2001: 18), dihadapkan pada permasalah pada setiap jenjang dan satuan pendidikan, khususnya pendidikan dasar dan menengah.

Dalam rangka pencapaian tujuan pendidikan yakni "Mencerdaskan kehidupan bangsa", berbagai masalah dapat muncul dan menghambat proses pendidikan di sekolah perlu diantisipasi, disikapi, ditanggulangi agar proses pendidikan tidak terpuruk dengan kejadiankejadian yang merugikan pendidikan itu sendiri. Masalah-masalah yang akan timbul tidak untuk dihindari, tetapi perlu dicari solusi untuk mengatasinya. Salah satu solusi untuk meminimalisir bahkan mencegah masalah-masalah yang akan terjadi yakni melaksanakan program pembimbingan dan konseling. Program ini dilaksanakan terutama untuk memberikan bantuan kepada siswa secara individual maupun secara kelompok untuk keluar dari permasalahannya.

Masalah dalam proses belajar siswa dapat muncul dalam diri individu mauppun dari luar individu dan keduanya dapat mengakibatkan kegagalan dalam belajarnya dan lebih fatal lagi terjadinya putus sekolah (drop out) yang akan melahirkan masalah baru dalam masyarakat (sosial) dengan berkelompoknya anak-anak putus sekolah yang melahirkan kelompok anak-anak jalanan yang berperilaku meresahkan warga masyarakat. Putus sekolah merupakan masalah yang berawal dari masalah yang tidak dituntaskan dari lingkungan pendidikan di sekolah. Hal ini banyak ditentukan oleh adanya pengelolaan sekolah dalam hal ini Kepala Sekolah yang kurang peka terhadap masalah di sekolah termasuk siswa-siswa yang bermasalah dalam belajar.

Pelaksanaan pendidikan di sekolah baik negeri maupun swasta senantiasa 
melaksanakan tiga bidang garapan yang meliputi bidang: (1) Administrasi, (2) Pengajaran dan (3) Bidang Pembinaan Pribadi Siswa.

Bidang pembinaan pribadi murid yang dikenal dengan program bimbingan dan konseling. Pelaksanaan program tersebut secara resmi dimulai sejak berlakunya kurikulum 1975, namun hingga sekarang masih banyak sekolah yang mengalami hambatan baik pada segi perencanaan, fasilitas penunjang sarana maupun prasarana yang diperlukan, maupun sikap terhadap kegiatan program tersebut.

Kegiatan program bimbingan dan konseling yang direncanakan secara terperinci dan mantap akan banyak memberikan manfaat dan keuntungan baik kepada siswa yang mendapatkan bimbingan maupun pada petugas yang menyelenggarakannya karena program bimbingan semacam itu dapat:

1. Memungkinkan petugas untuk menghemat waktu/biaya dengan menghindari kesalahan-kesalahan yang mungkin terjadi dan usaha coba-coba yang tidak menguntungkan.

2. Siswa-siswa akan mendapatkan pelayanan secara seimbang dan menyeluruh, baik dalam hal kesempatan maupun jenis pelayanan yang diperlukan.

3. Setiap petugas akan banyak mengetahui bilamana harus bertindak, dalam pada itu para petugas bimbingan akan menghayati pengalaman yang sangat penting untuk kemajuannya sendiri dan untuk kepentingan siswa yang dibimbingnya.

Hambatan-hambatan pelaksanaan program bimbingan di setiap sekolah, akan berbeda dari satu sekolah dengan sekolah yang lain. Hal ini tergantung pada kemampuan para pengelolah, kondisi sekolah, dsb. Salah satu faktor penting dan merupakan hambatan, dalam pelaksanaan bimbingan dan konseling adalah kurangnya kesadaran dan pemahaman pihak pengelolah tentang pentingnya program tersebut. Komponen kesadaran dan pemahaman pengelolah dianggap penting dan mendasar oleh karena pada dasarnya penerimaan diri seseorang terhadap sesuatu sangat mempengaruhi perilakunya terhadap obyek tersebut.

Masalah-masalah yang menghambat jalannya program bimbingan dan konseling, seperti kurangnya kesadaran dan pemahaman pihak pengelola, dalam hal ini para guru di sekolah dapat saja diatasi apabila kepala sekolah mempunyai sikap positif tentang adanya program bimbingan. Karena Kepala Sekolah sebagai pimpinan di sekolah mempunyai fungsi yang sangat menentukan kemajuan sekolah ia dapat menggerakkan, menanamkan kesadaran bawahannya untuk lebih giat melaksanakan tugas.

\section{METODE PENELITIAN}

\section{Metode Penelitian}

Metode yang digunakan dalam penelitian ini adalah metode survey yaitu pengumpulan informasi melalui data lapangan yang menggambarkan faktorfaktor yang berhubungan dengan peranan kepala sekolah, Guru BK, Wali Kelas, Tata Usaha dan pelaksanaan bimbingan dan konseling di SMK Negeri 1 Manado. Kerlinger dalam Sugiono (2001:7) mengatakan bahwa metode survey adalah penelitian yang dilakukan pada populasi besar maupun kecil, tetapi data yang dipelajari adalah data dan sampel yang diambil dari populasi tersebut, sehingga ditemukan kejadian-kejadian relatif, distribusi dan hubungan-hubungan antar variabel sosiologis maupun psikologis.

\section{Operasional Variabel}

Variabel dalam penelitian ini adalah peranan kepala sekolah dalam 
pelaksanaan bimbingan konseling di SMK Negeri 1 Manado. Peranan kepala sekolah adalah varibel bebas $\mathrm{X}_{1}$, Guru $\mathrm{BK}$ variabel $\mathrm{X}_{2}$, Wali Kelas variabel $\mathrm{X}_{3}$, Tata Usaha variabel $X_{3}$ sedangkan pelaksanaan bimbingan konseling adalah variabel terikat $\mathrm{Y}$.

Peranan kepala sekolah terdiri dari aspek-aspek: (1) bidang akademik yang berkenaan dengan proses belajar mengajar di dalam dan di luar sekolah; (2) bidang ketatausahaan dan keuangan sekolah; (3) bidang kesiswaan termasuk layanan bimbingan konseling; (4) bidang personalia/kepegawaian; (5) bidang gedung dan perlengkapan sekolah; (6) bidang peralatan pelajaran; dan (7) bidang hubungan sekolah dan masyarakat.

Peranan guru BK terdiri atas aspek-aspek: (1) bidang pelaksanaan bimbingan pribadi; (2) bidang pelaksanaan bimbingan social; (3) bidang pelaksanaan bimbingan belajar; dan (4) bidang pelaksanaan bimbingan karier

Peranan Wali Kelas terdiri dari aspek-aspek: (1) berperan sebagai pelayanan bimbingan dan konseling; (2) membantu guru BK dalam melaksanakan tugasnya; dan (3) memberi kesempatan dan kemudahan kepada siswa untuk mengikuti layanan bimbingan dan konseling di sekolah

Peranan tata usaha terdiri atas aspek-aspek: (1) menyusun kerja tata usaha sekolah; (2) pembinaan dan pengembangan karir pegawai tata usaha sekolah

Penyusunan administrasi perlengkapan sekolah; (3) penyusunan laporan pelaksanaan kegiatan pengurusan ketatausahaan secara berkala.

Pelaksanaan bimbingan konseling terdiri dari aspek-aspek:

1. Menyusun secara kolektif program bimbingan dan konseling yang bersifat menyeluruh dan dapat dilak- sanakan disesuaikan dengan kondisi sekolah.

2. Mengadakan pembinaan intern secara intensif yang dipimpin oleh kepala sekolah melalui rapat rutin, konferensi kasus dan sebagainya.

3. Mengusahakan adanya suatu sistem informasi yang berfungsi bagi keperluan bimbingan dan konseling terhadap siswa-siswa, guru-guru bidang studi lainnya dan orang tua.

4. Mengkoordinasikan kegiatan petugas bimbingan dan konseling dengan kegiatan-kegiatan guru bidang studi lainnya.

5. Memikirkan dan mengusahakan tersedianya kebutuhan sarana maupun prasarana untuk menunjang keberhasilan pelaksanaan program bimbingan dan konseling.

6. Merintis kerjasama bimbingan dan konseling antar sekolah, baik yang bersifat informasi dan pengalaman maupun dalam pemecahan kasus.

7. Merintis kerjasama dengan lembagalembaga yang ada hubungannya dengan pengembangan bimbingan dan konseling.

8. Membuat laporan pelaksanaan bimbingan dan konseling secara berkala maupun insidentil.

\section{Populasi dan Sampel}

\section{Populasi}

Populasi dalam penelitian ini adalah seluruh karakteristik yang berhubungan dengan peranan kepala sekolah, Guru BK, Wali Kelas, Tata Usaha dan pelaksanaan bimbingan konseling di SMK Negeri 1 Manado. Anggota populasi adalah seluruh siswa SMK Negeri Manado pada jurusan penjualan. 
Tabel 1: Anggota Populasi

\begin{tabular}{lccccc}
\hline & & \multicolumn{3}{c}{ Jenis kelamin } & \\
\cline { 5 - 6 } No & Jurusan & Kelas & L & P & Jumlah \\
\hline 1 & Penjualan & I-8 & 11 & 37 & 48 \\
\hline 2 & & I-9 & 13 & 37 & 50 \\
\hline 3 & & I-10 & 10 & 39 & 49 \\
\hline 4 & II-8 & 11 & 35 & 46 \\
\hline 5 & & II-9 & 9 & 38 & 47 \\
\hline & Jumlah & & $\mathbf{5 4}$ & $\mathbf{1 8 6}$ & $\mathbf{2 4 0}$ \\
\hline
\end{tabular}

\section{Sampel}

Ukuran sampel dalam penelitian ini ditentukan oleh peneliti sebesar $40 \%$ dari jumlah populasi atau $40 \% \times 240=$ 96

Tabel 2: Anggota Sampel

\begin{tabular}{|c|c|c|c|c|c|}
\hline \multirow[b]{2}{*}{ No } & \multirow[b]{2}{*}{ Jurusan } & \multirow[b]{2}{*}{ Kelas } & \multicolumn{2}{|c|}{ Jenis kelamin } & \multirow[b]{2}{*}{ Jumlah } \\
\hline & & & $\mathrm{L}$ & $\mathrm{P}$ & \\
\hline 1 & Penjualan & $\mathrm{I}-8$ & 5 & 15 & 19 \\
\hline 2 & & I-9 & 5 & 15 & 20 \\
\hline 3 & & I-10 & 4 & 16 & 20 \\
\hline 4 & & II-8 & 4 & 14 & 17 \\
\hline 5 & & II-9 & 4 & 15 & 19 \\
\hline & umlah & & 22 & 74 & 96 \\
\hline
\end{tabular}

\section{Teknik Pengumpulan Data}

Teknik pengumpulan data yang digunakan adalah angket untuk menjaring data tentang peranan kepala sekolah, Guru BK, Wali Kelas, Tata Usaha dan pelaksanaan bimbingan konseling di SMK Negeri 1 Manado. Selain angket digunakan wawancara dan observasi sebagai pengumpul data pelengkap.

\section{Analisis Data}

Selanjutnya data yang terjaring melalui angket dianalisis dengan teknik regresi dan korelasi. Untuk pengolahan data ini menggunakan analisis regresi dengan program computer SPSS-15.00 for Windows.

\section{HASIL PENELITIAN}

\section{Hasil Pengujian Hipotesis Pertama}

Berdasarkan hasil analisis data tentang peranan kepala sekolah, Guru
BK, Wali Kelas, Tata Usaha diperoleh bahwa skor terendah berada pada rentang $70-78$ yang dicapai 52 orang (54\%), skor tertinggi berada pada rentang 84 - 88 yang dicapai oleh 21 orang (22\%). Skor pada umumnya berada pada rentang 79 - 83 yang dicapai oleh 23 orang $(24 \%)$.

Berdasarkan hasil analisis data tentang peranan guru BK diperoleh bahwa skor terendah berada pada rentang $70-78$ yang dicapai 53 orang (55\%), skor tertinggi berada pada rentang 84 - 88 yang dicapai oleh 22 orang (23\%) Skor pada umumnya berada pada rentang 79 - 83 yang dicapai oleh 21 orang $(22 \%)$.

Berdasarkan hasil analisis data tentang peranan Wali Kelas diperoleh bahwa skor terendah berada pada rentang $70-78$ yang dicapai 52 orang (54\%), skor tertinggi berada pada rentang 84 - 88 yang dicapai oleh 21 orang (22\%) Skor pada umumnya berada 
pada rentang 77 - 83 yang dicapai oleh 57 orang $(23 \%)$.

Berdasarkan hasil analisis data tentang peranan Tata Usaha diperoleh bahwa skor terendah berada pada rentang 70 - 78 yang dicapai 52 orang (54\%), skor tertinggi berada pada rentang 84 - 88 yang dicapai oleh 19 orang $(20 \%)$ Skor pada umumnya berada pada rentang 79 - 83 yang dicapai oleh 25 orang $(26 \%)$.

Hal ini berarti mendukung hipotesis pertama yang menyatakan bahwa terdapat gambaran yang positif peranan kepala sekolah, Guru BK, Wali Kelas, Tata Usaha di SMK Negeri 1 Manado.

\section{Hasil Pengujian Hipotesis Kedua}

Hipotesis kedua menyatakan terdapat gambaran yang positif pelaksanaan bimbingan konseling di SMK Negeri 1 Manado. Berdasarkan hasil analisis data diperoleh skor terendah berada pada rentang 70 - 77 yang dicapai oleh 39 orang (41\%), skor tertinggi berada pada rentang 84 - 87 yang dicapai oleh 8 orang (8\%) Skor pada umumnya berada pada rentang 78 - 83 yang dicapai oleh 59 orang $(61 \%)$.

Hal ini berarti mendukung hipotesis kedua yang menyatakan bahwa terdapat gambaran yang positif pelaksanaan bimbingan konseling di SMK Negeri 1 Manado.

\section{Hasil Pengujian Hipotesis Ketiga}

Hipotesis ketiga menyatakan terdapat hubungan yang positif peranan kepala sekolah, Guru BK, Wali Kelas, Tata Usaha dalam pelaksanaan bimbingan konseling di SMK Negeri 1 Manado. Untuk menguji hipotesis ketiga menggunakan analisis korelasi dengan menggunakan program SPSS versi 15.00 diperoleh hasil $r=0,653 \quad(p=0,05)$. Koefisien korelasi sebesar 0,653 yang jatuh pada probabilitas $(0,05)$ hal ini menunjukkan bahwa Ho ditolak.

Hipotesis ketiga menyatakan terdapat hubungan yang positif peranan guru BK dalam pelaksanaan bimbingan konseling di SMK Negeri 1 Manado. Untuk menguji hipotesis ketiga menggunakan analisis korelasi dengan menggunakan program SPSS versi 15.00 diperoleh hasil $r=0,605 \quad(p=0,05)$. Koefisien korelasi sebesar 0,605 yang jatuh pada probabilitas $(0,05)$ hal ini menunjukkan bahwa Ho ditolak.

Hipotesis ketiga menyatakan terdapat hubungan yang positif peranan Wali Kelas dalam pelaksanaan bimbingan konseling di SMK Negeri 1 Manado. Untuk menguji hipotesis ketiga menggunakan analisis korelasi dengan menggunakan program SPSS versi 15.00 diperoleh hasil $\mathrm{r}=0,687 \quad(\mathrm{p}=0,05)$. Koefisien korelasi sebesar 0,687 yang jatuh pada probabilitas $(0,05)$ hal ini menunjukkan bahwa Ho ditolak.

Hipotesis ketiga menyatakan terdapat hubungan yang positif peranan Tata Usaha dalam pelaksanaan bimbingan konseling di SMK Negeri 1 Manado. Untuk menguji hipotesis ketiga menggunakan analisis korelasi dengan menggunakan program SPSS versi 15.00 diperoleh hasil $r=0,679 \quad(p=0,05)$. Koefisien korelasi sebesar 0,679 yang jatuh pada probabilitas $(0,05)$ hal ini menunjukkan bahwa Ho ditolak.

Artinya, peranan kepala sekolah, Guru BK, Wali Kelas, Tata Usaha mempunyai pengaruh positif dengan pelaksanaan bimbingan konseling, semakin tinggi peranan kepala sekolah, Guru BK, Wali Kelas, Tata Usaha akan diikuti dengan peningkatan pelaksanaan bimbingan konseling dan semakin rendah peranan kepala sekolah maka semakin rendah pula pelaksanaan bimbingan konseling di SMK Negeri 1 Manado. 


\section{PEMBAHASAN}

Di mana-mana kita sering mendengar orang mengucapkan istilah bimbingan dan penyuluhan, seperti bimbingan dan penyuluhan keluarga berencana, bimbingan dan penyuluhan agama, bimbingan dan penyuluhan hukum, dan sebagainya. Tetapi sayangnya, sering kali istilah bimbingan dan penyuluhan yang digunakan itu maksudnya tidak selalu persis sama dengan maksud bimbingan dan penyuluhan yang sesungguhnya sebagaimana dikemukakan dalam literatur-literatur ilmiah dari mana istilah itu berasal. Sehingga masih perlu dipertanyakan apakah yang dimaksud dengan bimbingan dan penyuluhan itu.

Bimbingan adalah suatu pemberian bantuan kepada individu yang dilakukan secara terus-menerus supaya individu tersebut dapat memahami dirinya sendiri sehingga ia anggap mengarahkan dirinya, dan bertindak wajar sesuai dengan tuntutan dan keadaan lingkungan, lingkungan sekolah, keluarga dan masyarakat.

Bimbingan dapat diartikan sebagai bagian dari keseluruhan program pendidikan yang membantu menyediakan kesempatan-kesempatan pribadi dan layanan-layanan petugas ahli dengan mana setiap individu dapat mengembangkan kemampuan-kemampuan dan kecakapan-kecakapannya secara penuh sesuai dengan yang diharapkan (Mortensen \& Schmuller, 1976:3).

Menurut Rochman Natawidjaya (1982:11) mengemukakan bahwa Bimbingan adalah suatu pemberian bantuan kepada individu yang dilakukan secara terus-menerus supaya individu tersebut dapat memahami dirinya sendiri sehingga ia anggap mengarahkan dirinya, dan bertindak wajar sesuai dengan tuntutan dan keadaan lingkungan, lingkungan sekolah, keluarga dan masyarakat. Selanjutnya menurut keadaan lingkungan sekolah, keluarga dan masyarakat

Hadadi Nawawi (1983:25) mengemukakan bahwa: Bimbingan adalah bantuan yang diberikan kepada individuindividu dalam menentukan pilihanpilihan dan mengadakan berbagai penyesuaian secara bijaksana dengan lingkungannya. Tujuan utama bimbingan adalah untuk mengembangkan setiap individu sesuai dengan kemampuannya (Jones, dalam Djumhur dan M. Surya 1975:10).

Tujuan bimbingan membantu murid-murid untuk mengembangkan pemahaman diri sendiri dengan kecakapan, minat dan pribadi, hasil belajar serta kesempatan yang ada; membuat proses sosialisasi dan sensivitas kepada kebutuhan-kebutuhan orang lain; membantu murid-murid untuk mengembangkan motif-motif intrinsic dalam belajar; sehingga tercapai kemajuan pengajaran yang berarti dan bertujuan memberikan dorongan di dalam pengarahan diri, pemecahan masalah, pengambilan keputusan dan ketertiban diri dalam proses pendidikan.

Fungsi bimbingan: fungsi pencegahan, fungsi penyaluran, fungsi perbaikan dan fungsi pemeliharaan.

Tugas-tugas pokok Kepala Sekolah mencakup 7 bidang sebagai berikut:

1. Bidang akademik yang berkenaan dengan proses belajar mengajar di dalam dan di luar sekolah.

2. Bidang ketatausahaan dan keuangan sekolah.

3. Bidang kesiswaan.

4. Bidang personalia/Kepegawaian.

5. Bidang Gedung dan Perlengkapan Sekolah.

6. Bidang Peralatan Pelajaran.

7. Bidang Hubungan sekolah dan Masyarakat.

Konseling adalah hubungan pribadi yang dilakukan secara tatap muka 
antara dua orang, dalam mana konselor melalui hubungan itu dan kemampuankemampuan khusus yang dimilikinya, menyediakan situasi belajar dalam mana konseling dibantu untuk memahami diri sendiri, keadaannya sekarang, dan kemungkinan keadaan masa depan yang dapat ia ciptakan dengan menggunakan potensi-potensi yang dimilikinya, demi untuk kesejahteraan baik pribadi maupun masyarakat, dan lebih jauh dapat belajar bagaimana memecahkan masalahmasalah dan menemukan kebutuhankebutuhan yang datang.

Selanjutnya menurut pendapat Tolbert (dalam Prayitno, 1994:101) menyatakan:

“...Konseling adalah hubungan pribadi yang dilakukan secara tatap muka antara dua orang, dalam mana konselor melalui hubungan itu dan kemampuan-kemampuan khusus yang dimilikinya, menyediakan situasi belajar dalam mana konseling dibantu untuk memahami diri sendiri, keadaannya sekarang, dan kemungkinan keadaan masa depan yang dapat ia ciptakan dengan menggunakan potensi-potensi yang dimilikinya, demi untuk kesejahteraan baik pribadi maupun masyarakat, dan lebih jauh dapat belajar bagaimana memecahkan masalah-masalah dan menemukan kebutuhan-kebutuhan yang datang".

Bertitik tolak dari ciri-ciri pokok pendapat di atas, dapatlah dirumuskan dengan singkat pengertian konseling yaitu:

Konseling adalah proses pemberian bantuan yang dilakukan melalui wawancara konseling oleh seorang ahli (disebut konselor) kepada individu yang sedang mengalami sesuatu masalah (disebut klien) yang bermuara pada teratasinya masalah yang dihadapi oleh klien.

\section{Peranan Guru BK dalam Pelaksanan Bimbingan Konseling di sekolah}

Pelaksanaan Bimbingan Konseling di sekolah merupakan salah satu faktor yang menentukan keberhasilan proses belajar mengajar di sekolah. Sebab proses keberhasilan belajar di sekolah melibatkan tiga bidang garapan yaitu: (1) bidang administrasi, (2) bidang pengajaran dan (3) bidang pembinaan pribadi siswa (bidang pemberian layanan bimbingan konseling). Oleh karena itu peranan guru kelas dalam pelaksanaan kegiatan Bimbingan Konseling di sekolah sangat penting dalam rangka mengefektifkan pencapaian tujuan pembelajaran.

Sardiman (2001:142) menyatakan bahwa ada sembilan peranan guru dalam kegiatan Bimbingan Konseling, yaitu: (1) Informator, guru BK diharapkan sebagai pelaksana cara mengajar informatif, laboratorium, studi lapangan, dan sumber informasi kegiatan akademik maupun umum, (2) Organisator, guru sebagai pengelola kegiatan akademik, silabus, jadwal pelajaran dan lain-lain, (3) Motivator, guru harus mampu merangsang dan memberikan dorongan serta reinforcement untuk mendinamisasikan potensi siswa, menumbuhkan swadaya (aktivitas) dan daya cipta (kreativitas) sehingga akan terjadi dinamika di dalam proses belajar-mengajar. (4) Direktor, guru harus dapat membimbing dan mengarahkan kegiatan belajar siswa sesuai dengan tujuan yang dicita-citakan, (5) Inisiator, guru sebagai pencetus ide dalam proses belajar-mengajar. (6) Transmitter, guru bertindak selaku penyebar kebijaksanaan dalam pendidikan dan pengetahuan, (7) Fasilitator, guru akan memberikan fasilitas atau kemudahan dalam proses belajar-mengajar, (8) Mediator, guru sebagai penengah dalam kegiatan belajar siswa, (9) Evaluator, guru mempunyai otoritas untuk 
menilai prestasi anak didik dalam bidang akademik maupun tingkah laku sosialnya, sehingga dapat menentukan bagaimana anak didiknya berhasil atau tidak.

Guru BK menempati posisi yang strategis dalam upaya pembinaan peserta didik, baik untuk tujuan preventif, kuratif, maupun rehabilitatif. Peranan guru BK (bimbingan dan konseling) di sekolah sangat bermakna untuk dapat membantu siswa yang bermasalah.

Peran wali kelas dalam pelaksanaan bimbingan dan konseling di sekolah sebagai pengelola kelas tertentu dalam pelayanan bimbingan dan konseling, wali kelas berperan:

1. Membantu guru pembimbing/konselor melaksanakan tugas-tugasnya, khususnya di kelas yang menjadi tanggung jawabnya;

2. Membantu Guru Mata Pelajaran melaksanakan peranannya dalam pelayanan bimbingan dan konseling, khususnya di kelas yang menjadi tanggung jawabnya;

3. Membantu memberikan kesempatan dan kemudahan bagi siswa, khususnya dikelas yang menjadi tanggung jawabnya, untuk mengikuti/menjalani layanan dan/atau kegiatan bimbingan dan konseling;

4. Berpartisipasi aktif dalam kegiatan khusus bimbingan dan konseling, seperti konferensi kasus; dan

5. Mengalihtangankan siswa yang memerlukan layanan bimbingan dan konseling kepada guru pembimbing/konselor.

\section{Tugas Pokok dan Fungsi Bidang Tata Usaha Sekolah, yaitu:}

1. Kegiatan administrasi umum yang bersifat pelayanan umum meliputi;
a) Pembuatan Program Kerja Tata Usaha
b) Penyusunan ruang-ruang kelas
c) Ketenagaan
d) Rapat dinas

e) Upacara Sekolah

2. Kegiatan administrasi kesiswaan

a) Penyediaan format bio data dalam rangka PSB

b) Penyediaan saran prasarana dalam rangka MOS

c) Kebutuhan administrasi Bimbingan dan Konseling

d) Kegiatan ekstra kurikuler

3. Kegiatan administrasi sarana dan prasarana

a) Inventaris perlengkapan kelas, kantor, alat dan bahan laboratorium, serta perpustakaan

b) Pengadaan barang

c) Pemeliharaan barang inventaris sarana pembelajaran

d) Pemeliharaan sarana fisik

4. Kegiatan administrasi keuangan

a) Usulan daftar gaji guru \& karyawan

b) Pembagian gaji/ kesra/ honor jam mengajar

c) Penerimaan uang iyuran Komite Sekolah

d) Pembuatan/ penyetoran SPJ

e) Penyetoran pajak penghasilan

5. Kegiatan admistrasi ketatausahaan

a) Adminstrasi ketenagaan

b) Administrasi siswa; buku induk, buku klaper, dan buku mutasi

c) Penghitungan angka kredit jabatan guru

d) Usul kenaikan pangkat guru dan karyawan

e) Pembuatan usul PAK

f) Pembuatan SK kenaikan Gaji Berkala guru dan karyawan

g) Pengagendaan, pengarsipan surat menyurat masuk dan keluar

h) Laporan ketatausahaan

i) Pembuatan/ pengetikan DP3 guru dan karyawan

Tata usaha sekolah mempuyai tugas melaksanakan ketatausahaan sekolah, dan bertanggung jawab kepada 
sepala sekolah dalam kegiatan-kegiatan sebagai berikut:

a. penyusunan program kerja tata usaha sekolah;

b. pengelolaan keuangan sekolah;

c. pengurusan administrasi ketenagaan dan siswa;

d. pembinaan dan pengembangan karir pegawai tata usaha sekolah;

e. penyusunan administrasi perlengkapan sekolah;

f. mengkoordinasikan dan melaksanakan $6 \mathrm{~K}$;

g. penyusunan laporan pelaksanaan kegiatan pengurusan ketatausahaan secara berkala.

\section{PENUTUP}

\section{Kesimpulan}

Kesimpulan didasarkan atas temuan-temuan penelitian pada Bab IV / hasil penelitian, sebagai berikut:

1. Terdapat gambaran yang positif peranan kepala sekolah, Guru BK, Wali Kelas, Tata Usaha di SMK Negeri 1 Manado.

2. Terdapat terdapat gambaran yang positif pelaksanaan bimbingan dan konseling di SMK Negeri 1 Manado.

\section{DAFTAR RUJUKAN}

Bimo Walgito, 1984, Bimbingan dan Penyuluhan di Sekolah, Fakultas Psikologi UGM, Yogyakarta.

Bernard, Harold W. 1977. Principle of Guidance, New York; Harper \& Raw Publishers.

Crow, Lester D. \& Crow, Alice. 1960. An Introduction to Guidance, New York: American Book Company.

\footnotetext{
Depdiknas, 2001, Manajemen Peningkatan Mutu Berbasis Sekolah, Jakarta.
}

3. Terdapat hubungan yang positif peranan kepala sekolah, Guru BK, Wali Kelas, Tata Usaha dengan pelaksanaan bimbingan dan konseling di SMK Negeri 1 Manado. Artinya, peranan kepala sekolah, Guru BK, Wali Kelas, Tata Usaha mempunyai pengaruh positif dengan pelaksanaan bimbingan dan konseling, semakin tinggi peranan kepala sekolah akan diikuti dengan peningkatan pelaksanaan bimbingan dan konseling dan semakin rendah peranan kepala sekolah maka semakin rendah pula pelaksanaan bimbingan dan konseling di SMK Negeri 1 Manado.

\section{Saran}

1) Guru pembimbing di sekolah senantiasa memberikan informasi kepada siswa tentang pelayanan bimbingan konseling yang bisa dimanfaatkan oleh siswa.

2) Sekolah dapat memberikan fasilitas yang diperlukan dalam pelaksanaan layanan bimbingan konseling di sekolah.

3) Siswa dapat memanfaatkan pelayanan bimbingan konseling di sekolah.

Handari Nawawi, H. 1983, Organisasi Sekolah dan Pengelolaan Kelas, Jakarta, PT. Gunung Agung.

I. Djumhur dan Moh. Surya. 1975. Bimbingan dan penyuluhan di Sekolah, Bandung: CV. Ilmu.

Mortensen, D.G \& A.M. Schmuller, 1976. Guidance in Today's School, New York: John Wiley \& Sons Inc. 
Natawidjaja, R. 1982, Peranan ganda dalam Bimbingan di Sekolah, Bandung, CV. Abardin.

Prayitno dan Erman Amti 1994. DasarDasar Bimbingan dan Konseling. Jakarta: Rineka Cipta.

Indeks

guru ...................... 1, 42, 43, 45, 48, 49 konseling ... 1, 41, 42, 43, 44, 45, 46, 47, $48,49,50$

mutu 41

pendidikan $1,41,42,47,48$
Sardiman. 2001. Interaksi dan Motivasi Belajar-Mengajar. Jakarta: Raja Grafindo Persada.

Suradi-S.A., 1983, Bagaimanakah Guru Pembimbing di Sekolah Jurusan Psikologi Pendidikan dan Bimbingan FIP IKIP Ujung Pandang.

Pendidikan................................... 1, 50

prestasi ......................................... 41, 48 sekolah 1, 41, 42, 43, 44, 45, 46, 47, 48, 49,50

siswa. $41,42,43,44,48,49,50$ 